\title{
Mummified Fruit as a Source of Inoculum and Disease Dynamics of Olive Anthracnose Caused by Colletotrichum spp.
}

\author{
Juan Moral and Antonio Trapero
}

Departamento de Agronomía, ETSIAM, Universidad de Córdoba, Campus de Rabanales, Edif. C4, 14071 Córdoba, Spain. Accepted for publication 15 June 2012.

\begin{abstract}
Moral, J., and Trapero, A. 2012. Mummified fruit as a source of inoculum and disease dynamics of olive anthracnose caused by Colletotrichum spp. Phytopathology 102:982-989.

Anthracnose, caused by Colletotrichum spp., is a destructive disease of olive fruit worldwide. The objective of this study was to investigate the influence of agronomical and weather factors on inoculum production using detached olive fruit and on the development of epidemics in the field. The pathogen produced very large numbers of conidia on rotted $\left(>1.87 \times 10^{8}\right.$ conidia/fruit) or mummified $\left(>2.16 \times 10^{4}\right.$ conidia/fruit $)$ fruit under optimal conditions. On mummified fruit, conidial production was highest on mummies incubated at 20 to $25^{\circ} \mathrm{C}$ and $96 \mathrm{~h}$ of wetness. Repeated washings of mummies reduced conidial production until it was very low after five washings. When mummies were placed in the tree can-

opy, conidial production was not reduced after 6 months (May to October); but, when they were held on the soil or buried in the soil, conidial production comparatively decreased up to 10,000 times. Anthracnose epidemics on susceptible 'Hojiblanca' and 'Picudo' during three seasons (2005-08) were influenced by rainfall, temperature, and fruit ripening, and had three main phases: the latent period (May to October); the onset of the epidemic, which coincided with the beginning of fruit ripening (early November); and disease development, which was predicted by the Weibull model (November to March). No epidemics developed on the susceptible cultivars during the driest season (2007-08) or on the resistant 'Picual' olive during any of the three seasons. These results provide the basis for a forecasting system of olive anthracnose which could greatly improve the management of this disease.
\end{abstract}

Anthracnose is the most important fruit disease of olive (Olea europaea L.) throughout the world, particularly in the humid areas where susceptible cultivars are grown, such as Portugal or the Catalonia and Andalusia regions of Spain (16,20,28). Andalusia (southern Spain) is the largest olive-growing region in the world ( $>1.5$ million ha) and, in some provinces, such as Jaén, all of the land used for agriculture is planted with olive (1).

Olive anthracnose is caused by the fungal pathogens Colletotrichum acutatum J. H. Simmonds and C. gloeosporioides (Penz.) Penz. \& Sacc. (15). Based on DNA sequences of the internal transcribed spacer (ITS) rDNA and $\beta$-tubulin gene regions, however, $C$. acutatum has been recently subdivided into $C$. acutatum, C. fioriniae, and C. simmondsii (27), with $C$. acutatum and $C$. simmondsii being the dominant species in the central Andalusian region and Portugal (19).

In Andalusia, the life cycle of $C$. acutatum on olive has been recently elucidated (20). Infection occurs at all stages of fruit development from flower bud emergence to ripening. After infection of the developing fruit, the fungus enters a quiescent period from which it emerges during fruit ripening in the autumn-early winter season, causing fruit rot and the production of abundant conidia (20). During this season, conidia can be rain splashed to other fruit and cause secondary infections before the fruit is harvested in late autumn or early winter; thus, the disease is polycyclic, with three or fewer secondary cycles. When the temperature rises and the relative humidity decreases, rotten fruit are mummified (31). A toxin produced by the pathogen in the infected fruit causes leaf wilting and branch dieback symptoms (20). Although the pathogen infects the leaves and shoots of olive, fungal conidiomata (acervuli) or conidial masses do not develop on these tissues in

Corresponding author: A. Trapero; E-mail address: trapero@uco.es

http://dx.doi.org/10.1094/PHYTO-12-11-0344

(c) 2012 The American Phytopathological Society
Andalusia (20) unless the infected tissues are incubated in humid chambers for $>1$ month (J. Moral and A. Trapero, unpublished data). Mummified fruit are the most important inoculum source for the disease. Mateo-Sagasta (17) indicated that the fungus might survive in mummies on the soil surface. Other authors, however, found that the fungus survives as mummies in the olive canopy because mummies on the soil surface are buried by soil cultivation or destroyed by insects and secondary invaders $(6,28)$. The effects of environmental conditions and the susceptibility of olive cultivars on inoculum production by infected or mummified fruit are unclear. In addition, estimation of the possible risk of fruit infection should be based on an understanding of seasonal patterns of inoculum production on mummified fruit and of factors affecting fruit infection. In other countries, such as Greece, Italy, and Australia, infected leaves are a secondary inoculum source because the pathogen sometimes develops acervuli on these tissues $(13,14,26,35)$.

Quantitative comparisons of plant epidemics help researchers evaluate the effects of various disease management strategies and tactics on disease dynamics (11). The progress of olive anthracnose epidemics is influenced by several factors, including weather conditions $(9,19,28,30)$, cultivar susceptibility $(17,21,19)$, and fruit maturity $(17,18)$. Nevertheless, most of these studies have been carried out under controlled or field conditions very different from those in the Mediterranean Basin (9). Research is needed on the biology and dynamics of anthracnose epidemics in the Mediterranean region because this region is the world's largest producer of olives and is the center of olive diversity (3).

In this study, laboratory and field experiments were conducted to obtain the information required for a decision support system for the management of olive anthracnose. The first objective of this study was to quantify conidial production from rotted and mummified fruit as affected by temperature, wetness duration, and other factors in the Mediterranean region. The second objective was to determine the effects of cultivar resistance and 
fruit ripeness on the development of epidemics studied during three seasons. A preliminary report has been published (22).

\section{MATERIALS AND METHODS}

Production of soapy fruit and mummified fruit. Ripe olive fruit were collected from healthy field-grown trees in the province of Córdoba (southern Spain). Fruit of the following three widely grown olive cultivars with different degrees of resistance to anthracnose were used: 'Hojiblanca' (highly susceptible), 'Picual' (resistant), and 'Picudo' (highly susceptible). These cultivars also differ in their time of ripeness, having been classified as late, early, and very late, respectively $(2,21)$. Fruit were washed, disinfested by immersing them in a $10 \%$ solution of commercial bleach $(\mathrm{Cl}$ at $50 \mathrm{~g} / \mathrm{liter})$ in sterile water for $1 \mathrm{~min}$, air dried, and sprayed with a conidial suspension $\left(10^{5}\right.$ conidia/ml $)$ as previously reported (18). Inoculations were performed with isolate Col-87 of C. acutatum-group A4; this group, which was classified according to its ITS $5.8 \mathrm{~S}$ and $\beta$-tubulin regions (29), is the pathogenically dominant group in central Andalusia (J. Moral and A. Trapero, unpublished data). Inoculated fruit were incubated between two layers of filter paper connected with water at the bottom of humidity chambers (plastic containers, 22 by 16 by $10 \mathrm{~cm}^{3}$, with $100 \%$ relative humidity $[\mathrm{RH}])$ at $23 \pm 2{ }^{\circ} \mathrm{C}$ under fluorescent

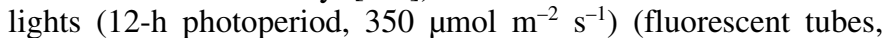
Cool-White VHO; Sylvania, Danvers, MA). Olive fruit that became completely rotted and that produced abundant conidia in a gelatinous matrix (i.e., "soapy fruit") were removed from the humidity chambers 1 month after inoculation for use in experiments. The soapy fruit were incubated in the same plastic containers with natural soil added for an additional 21 days to produce mummified fruit.

Quantification of conidial production from soapy fruit and mummies. For quantification of conidial production in the experiments described later in this article, soapy fruit or mummies were placed in 1.0- or 0.5-liter Erlenmeyer flasks with 100, 300, or $500 \mathrm{ml}$ of sterile water and Tween 20 at $1.5 \mathrm{ml} / \mathrm{liter}$ plus a magnetic stir-bar, depending on the experiment. For removal of conidia from infected fruit, flasks were placed successively in an ultrasonic bath (Selecta, Barcelona, Spain) for $5 \mathrm{~min}$ and in a magnetic agitator (Agimatic-N; Selecta) for $5 \mathrm{~min}$. The inoculum density of $C$. acutatum was measured with a hemacytometer, and the total number of conidia was calculated according to the volume of water. With this information (and data for fruit surface area), the conidial production per surface area of fruit was calculated. The area of each fruit was calculated as the area of a sphere $\left(\pi \mathrm{d}^{2}\right)$ whose diameter was the mean of two perpendicular diameters. Viability of the conidia, as determined by assessment of germination in the flasks or on acidified potato dextrose agar (PDA) plus copper sulfate (20), was always $>85 \%$.

Effect of cultivar on conidial production from soapy fruit. Conidial production from soapy fruit of Hojiblanca, Picual, and Picudo was determined as described in the previous section. The experiment was arranged in a completely randomized design with five replicates of 10 fruit/cultivar. The experiment was conducted twice and the data presented are the treatment averages of two experiments because experimental error variances were homogeneous and there were no significant differences between the experiments within cultivar. Data were analyzed using the Kruskal-Wallis test and mean ranks of cultivars were compared at $P=0.05$ using Dunn's test. Data from this experiment and other experiments were analyzed with SPSS (version 14; SPSS Inc., Chicago), except as noted.

Effect of temperature on conidial production from mummified fruit. Mummified fruit of Hojiblanca were incubated in humid chambers in continuous dark at intervals of 5 to $35^{\circ} \mathrm{C}$ and conidial production was measured after $72 \mathrm{~h}$. Each temperature was represented by three replicate humidity chambers (20 mum- mified fruit per chamber) and the experiment was conducted twice. Data from both experiments were averaged because variances were homogeneous by the $F$ test and Student's $t$ test did not detect significant differences between experiments when it was applied separately for each temperature. Regression analysis was performed on temperature means averaged over all replications. Conidial production at temperature $T$ [i.e., $Y_{(T)}$ ] was estimated from a temperature response function, $f_{(T)}$, and a maximum value $\left(C P_{\max }\right)$ of conidial production, which are analogous to the response function and maximum value of disease severity used by Magarey et al. (12) to describe the effect of wetness duration on infection:

$$
Y_{(T)}=f_{(T)} \times C P_{\max }
$$

where $f_{(T)}$ is Yin's nonlinear model (34) that uses the pathogen's cardinal temperatures to estimate the shape parameter and temperature response:

$$
f_{(T)}=\left(\frac{T_{\max -} T}{T_{\max }-T_{o p t}}\right)\left(\frac{T-T_{\min }}{T_{o p t}-T_{\min }}\right)^{\left(\frac{T_{o p t-} T_{\min }}{T_{\max }-T_{o p t}}\right)}
$$

where $T=$ mean temperature $\left({ }^{\circ} \mathrm{C}\right)$ during the incubation period, $T_{\min }=$ minimum temperature for sporulation, $T_{\max }=$ maximum temperature for sporulation, and $T_{\text {opt }}=$ optimum temperature for sporulation. The observed data from the experiments were compared with model predictions of $Y_{(T)}$ based on the coefficient of determination $\left(R^{2}\right)$, coefficient of determination adjusted for degrees of freedom $\left(R_{a}^{2}\right)$, the root mean square error (RMS), and the pattern of residuals (11). Magarey's model was selected after consideration of other models, such as the Analytis $\beta$ function and the Schödter angular model $(7,33)$.

Effect of wetness period on conidial production on mummified fruit. The effect of wetness period on conidial production on mummified fruit was studied using mummies of Hojiblanca that were incubated in humid chambers in the dark for $0,12,24,48,72,96$, or $168 \mathrm{~h}$ at $23 \pm 2^{\circ} \mathrm{C}$. After these incubations, conidial production on mummified fruit was assessed as described above. Each wetness period was represented by five humid chambers (20 mummies per chamber) and the experiment was conducted twice. Data from both experiments were averaged according to the criteria noted above in the experiment on the effect of temperature. Linear regression was used to evaluate the relationships between the length of the wetness period and conidial production.

Effect of repeated washings on conidial production from mummified fruit. Mummies of Hojiblanca were subjected to successive incubation-washing treatments to determine the effect of repeated rainfall events on conidial production. The mummies were incubated in humid chambers in the dark for $96 \mathrm{~h}$ at $23 \pm$ $2{ }^{\circ} \mathrm{C}$, and conidial production was assessed as described above. The same mummified fruit were then dried at room temperature for 1 week before they were hydrated in humid chambers for $96 \mathrm{~h}$ under the same conditions and conidial production was assessed again. The same process was repeated 14 times. Five humid chambers (20 mummified fruit per chamber) were used and the experiment was conducted twice. Data from both experiments were averaged according to the criteria noted above in the experiment on the effect of temperature. A logarithmic model fitted by nonlinear regression was used to study the relationship between accumulated conidial production and the number of washing treatments. Goodness of fit was evaluated using $R^{2}, R_{a}^{2}$, the pattern of residuals, and the number of iterations required by the Levenberg-Marquardt algorithm to converge on the parameter estimated (Statistix 9; Analytical Software, Tallahassee, FL).

Conidial production on mummified fruit that were placed in the tree canopy, placed on the soil surface, or buried in the 
soil. This experiment was conducted in a Picual orchard located at the Alameda del Obispo Center of the Andalusian Institute for Research and Formation in Agriculture and Fishery (IFAPA in Spanish) in Córdoba, southern Spain $\left(37.51^{\circ} \mathrm{N}, 4.80^{\circ} \mathrm{W}\right.$, altitude $110 \mathrm{~m})$. The soil of the orchard was classified as TypicXerofluvent of sandy-loam texture and climatic conditions were typical of the Mediterranean region, with a mean annual precipitation of $620 \mathrm{~mm}$ and a marked summer drought $(<30 \mathrm{~mm}$ of rain from June through September). The experimental orchard was managed according to the practices used in commercial olive orchards in Andalusia (1). At the beginning of May 2006 and 2008, mummies were placed inside nylon mesh bags (10 mummies/bag). Each year, 90 nylon bags were placed in the olive canopy, placed on the soil surface under the tree canopy, or buried in the soil at $5 \mathrm{~cm}$ of depth under the tree canopy ( 6 bags per each of five repeated trees per placement). One nylon bag from each placement and tree were collected monthly from May to October, and conidial production in humid chambers was assessed as described earlier. Conidial production (mean and standard error of means) was calculated monthly for each year.

Dynamics of fruit infection in the field. In all, 18 olive trees (6 each of Hojiblanca, Picual, and Picudo) were selected to study the effects of cultivar resistance and fruit ripeness on the development of anthracnose epidemics. The three cultivars were planted in an agronomical trial in 1987 with a 7-by-7-m spacing and with one trunk per tree. The trees were located in the La Mina orchard of the IFAPA Center in Cabra, Córdoba Province $\left(37.28^{\circ} \mathrm{N}, 4.26^{\circ} \mathrm{W}\right.$, altitude $\left.547 \mathrm{~m}\right)$. The climate is typical of the Mediterranean region, with a mean annual precipitation of 702 $\mathrm{mm}$ and a marked summer drought $(<30 \mathrm{~mm}$ of rain from June through September). The experimental orchard was managed according to the practices used in commercial olive orchards in Andalusia (1).

At the beginning of October of each year, one branch with $\approx 110$ fruit at the four cardinal directions (between 420 and 460 fruit per tree) was randomly marked in the canopy of each tree. The fruit were assessed every 1 to 3 weeks from November to March for anthracnose symptoms and ripeness (color class from 0 [green fruit] to 4 [black fruit]) (2). In addition, 1,100 to 1,500 asymptomatic fruit of each cultivar were collected arbitrarily and the percentage of fruit with latent infections of $C$. acutatum was determined every 2 to 3 weeks from November to March using the herbicide $\mathrm{N}, \mathrm{N}^{\prime}$-dimethyl-4,4'-bipyridinium dichloride (Paraquat) (20). The number of fallen fruit with and without symptoms was assessed from a total of $4 \mathrm{~m}^{2}$ of soil surface per tree $\left(1 \mathrm{~m}^{2}\right.$ per cardinal direction) that was marked using four $1-\mathrm{m}^{2}$ wooden frames for each tree. The numbers of symptomatic and asymptomatic fruit on the soil surface were counted every 1 to 2 weeks from November to March and the fruit were removed from the frames after each count. The study was carried out during three agronomical seasons: 2005-06, 2006-07, and 2007-08. In each season, six different olive trees per cultivar were selected in the same agronomical trial. The accumulated proportion of symptomatic fruit in the canopy plus on the soil was calculated for each replicate tree using the following formula:

$$
I=\frac{1}{N} \sum_{t=0}^{n} S c t+(D t \times S s t)
$$

where $I$ is the accumulated proportion of symptomatic fruit per tree at the $t$ th observation, Sct is the number of symptomatic fruit in the olive canopy at the $t$ th observation, $D t$ is the number of fallen marked fruit at the $t$ th observation, $S s t$ is the proportion (0 to 1) of symptomatic fruit on the soil surface at the $t$ th observation, $n$ is the total number of observations, and $N$ is the number of marked fruit $(\approx 440)$. Disease progress curves were created for the proportion of affected fruit over time in days from the date of appearance of the first affected fruit in the experimental trial at approximately the first week of November. The nonlinear form of the Weibull model was evaluated for goodness-of-fit to the set of disease progress curves using nonlinear regression with the Marquardt algorithm as described above. The Weibull model is a generalized, simple model that includes rate and shape parameters, which allows it to generate a wide variety of response curves according to the equation:

$$
Y=A\left(1-\exp \left\{-[B(t-C)]^{D}\right\}\right)
$$

where $Y=$ accumulated incidence index ( 0 to 1$), A=$ upper asymptote parameter (i.e., upper limit of $Y$ ), $B=$ scale parameter (i.e., intrinsic rate of $Y$ increase over time), $C=$ location parameter (i.e., length of delay before the onset of the epidemic development), $D=$ shape parameter (i.e., location of inflection point), and $t=$ time of disease assessment in days after the first week of November (24). In addition, area under the disease progress curves (AUDPCs) were calculated for each curve by trapezoidal integration. Finally, linear regression was used to evaluate fruit ripening $(F r)$ over time $(t)$ according to $F r=a \times b t$, where $b=$ ripening rate $\left(\right.$ day $\left.^{-1}\right)$. Fruit ripening was evaluated from the first week of November of each year until the fruit were completely ripe (i.e., black). The effect of cultivar on the dependent variables was studied separately for each season because of important differences between weather conditions among years. Dependent variables (parameters of the Weibull model $[A, B, C$, and $D]$, final incidence, and AUDPC) were subjected to analysis of variance (ANOVA), and means were compared with the Fisher's protected least significant difference test at $P=0.05$. For assessment of the effect of the cardinal position of fruit on the tree, ANOVA was performed using each tree as a block. The relationship between ripening rate $(b)$ of each olive tree and all dependent variables was studied using Pearson's correlation test. For each cultivar, linear regression was used to evaluate the fruit ripening rate $(b)$ over final incidence and regression lines of cultivars were compared based on their homogeneity of variances, slopes, and intercepts (Statistix 9; Analytical Software).

\section{RESULTS}

Effect of cultivar on conidial production from soapy fruit. The pathogen produced very large numbers of conidia on soapy fruit (i.e., from $1.87 \times 10^{8}$ to $1.04 \times 10^{9}$ conidia/fruit). According to the Kruskal-Wallis test, conidial production on soapy fruit differed $(P=0.0004)$ among cultivars. Colletotrichum acutatum produced more conidia on the susceptible Picudo than on the resistant Picual. The production of conidia did not differ $(P>$ 0.05) between the susceptible Hojiblanca and the other two cultivars (Fig. 1A). The number of conidia per unit of fruit surface was smaller on the resistant Picual than on the susceptible Hojiblanca and Picudo $(P=0.0134)$ but did not differ between the susceptible cultivars $(P>0.05)$ (Fig. 1B).

Effect of temperature on conidial production on mummified fruit. Temperature significantly $(P<0.0001)$ influenced conidial production on mummified fruit. Viable conidia were detected at all temperatures studied (Fig. 2). The fewest conidia were produced at 5 and $35^{\circ} \mathrm{C}$, with fewer at 35 than at $5^{\circ} \mathrm{C}$. Conidial production increased with increasing temperatures to a maximum near $20^{\circ} \mathrm{C}$ and decreased between 25 and $35^{\circ} \mathrm{C}$. This relationship was well described by equation 1 (Fig. 2), for which the parameters $T_{\min }, T_{\max }$, and $T_{\text {opt }}$ were established according to the experimental data and data from mycelial growth of the pathogen in culture media $(8,10)$ as 0,35 , and $22^{\circ} \mathrm{C}$, respectively. Thus, equation 2 can be rewritten as

$$
f_{(T)}=(2.6923-T / 13) \times(T / 22)^{1.6923}
$$


Comparison of the observed data and the data generated by equation 5 indicates that $R^{2}=0.866, R_{a}^{2}=0.839$, and $\mathrm{RMS}=$ 1.248 .

Effect of wetness period on conidial production from mummified fruit. The mummified olive fruit increased substantially in size when they were hydrated in humid chambers at $23 \pm 2{ }^{\circ} \mathrm{C}$. Wetness period significantly $(P=0.0032)$ affected conidial production of $C$. acutatum on mummified fruit and conidial production per unit area of fruit surface increased linearly with increasing wetness duration from 0 to $96 \mathrm{~h}$ (Fig. 3). The linear trend was significant $(P=0.0006)$ but the quadratic or cubic trends were not significant $(P>0.05)$. The following regression line fit the data well: $Y=2.1592+0.0859 X$, in which $Y=$ conidial production $\left(\times 10^{4}\right)$ and $X=$ wetness duration $(\mathrm{h})$ (Fig. 3). The slope parameter was significantly different from zero $(P<0.0001) ; R^{2}$ and $R_{a}{ }^{2}$ were 0.960 and 0.950 , respectively. Conversely, there was a substantial reduction in number of conidia per unit area of surface $\left(3.6 \times 10^{4}\right.$ conidia $\left./ \mathrm{mm}^{2}\right)$ when the wetness duration was $168 \mathrm{~h}$. At this time of incubation, the mummified fruit were washed and heavily colonized by saprophytic fungi, mainly species of Mucor and Rhizopus, and some bacteria, and these apparently inhibited the production of conidia by $C$. acutatum.

Effect of repeated washings on conidial production from mummified fruit. The cumulative number of viable conidia of $C$. acutatum produced on mummified olive fruit increased markedly with up to five incubation-washing treatments and then remained or increased slightly at this level according to the fitted asymp-
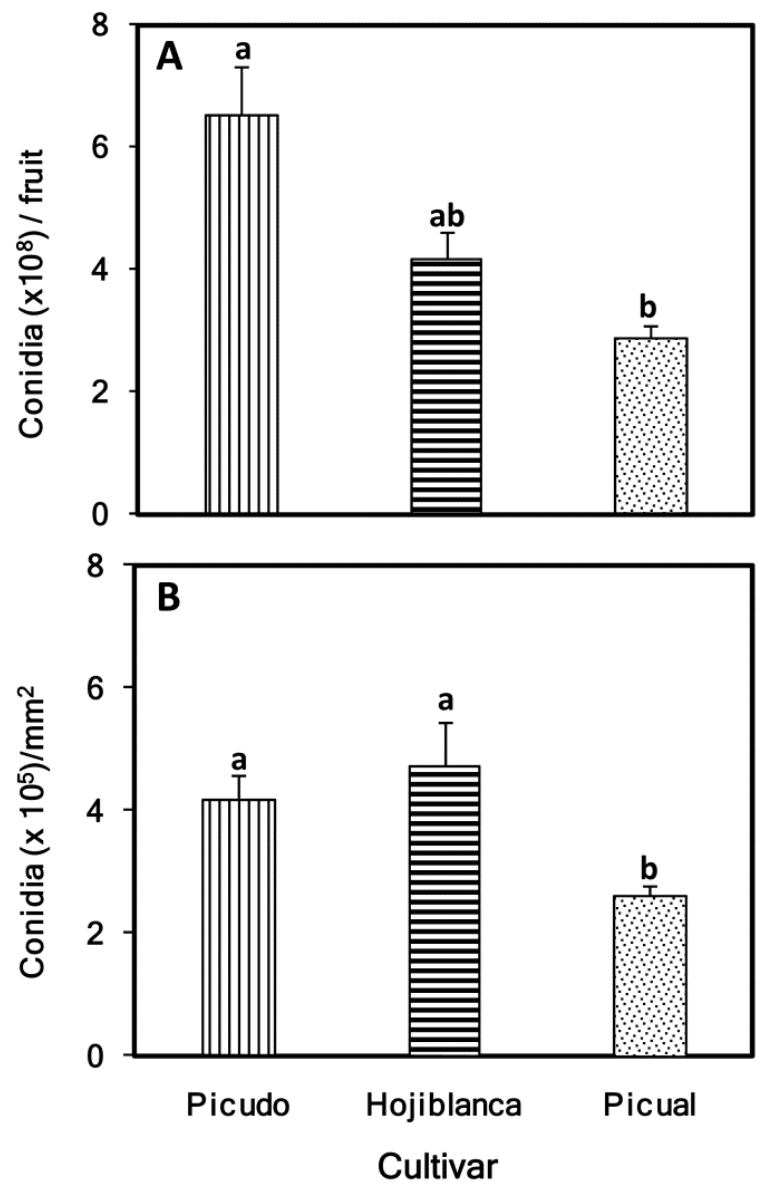

Fig. 1. Effect of cultivar on conidial production by Colletotrichum acutatum on "soapy" olive fruit. A, Number of conidia produced per soapy fruit. B, Number of conidia produced per unit of surface area (square millimeters) of soapy fruit. Bars represent the standard error of the mean. Columns with the same letters are not significantly different $(P=0.05)$ according to the KruskalWallis test and the Dunn's test for multiple comparison of mean ranks. totic model (Fig. 4). According to this model, the asymptote was at $\approx 10^{5}$ conidia $/ \mathrm{mm}^{2}$ of mummified fruit. The asymptotic model that best described the influence of the washing treatment on inoculum production was $Y=10.1751-3.2098 \times 0.5923^{X}$, in which $Y=$ cumulative conidial production $\left(\times 10^{4}\right)$ and $X=$ number of washing treatments (Fig. 4). All estimated parameters of the equation were significant $(P<0.05)$, and $R^{2}$ and $R_{a}{ }^{2}$ were 0.933 and 0.921 , respectively.

Conidial production on mummified fruit that were placed in the tree canopy, placed on the soil surface, or buried in the soil. From May to October 2006 and 2008, the pathogen produced viable conidia on mummified fruit that were placed in all three locations (Fig. 5). Between $10^{3}$ and $10^{4}$ times more conidia were produced on mummies in the tree canopy (aerial mummies) than on mummies on the soil surface or buried in the soil. Mummies on or in the soil were rapidly colonized by saprophytic fungi, mainly species of Alternaria, Fusarium, and Mucor (data not shown). In both years, the number of conidia per unit surface area of an aerial mummy decreased slightly with time but peaked in October 2006 and September 2008, which coincided with the first rainfall after summer (Fig. 5).

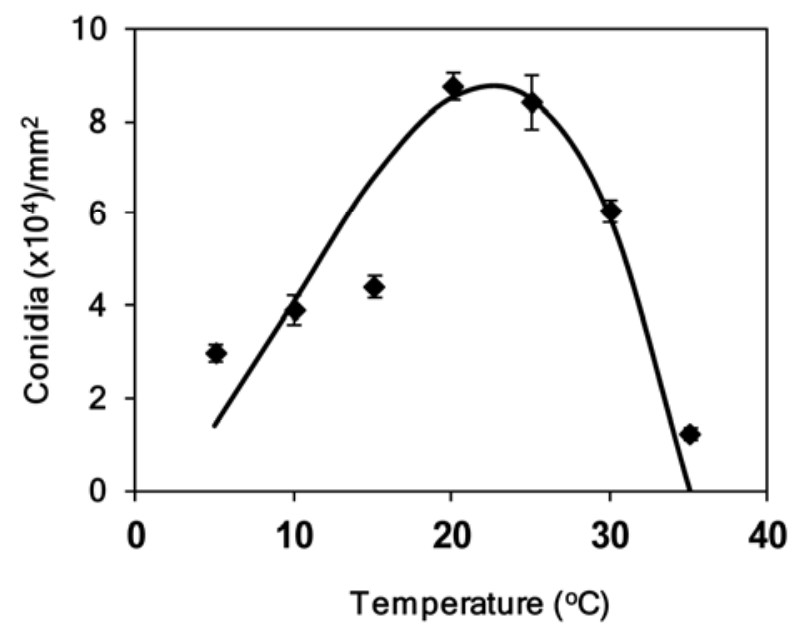

Fig. 2. Effect of temperature on the number of Colletotrichum acutatum conidia produced per unit surface area of mummified 'Hojiblanca' olive fruit. Points are the means of 60 replicate mummies, and bars represent the standard error of the mean. The line shows the fit of Yin's nonlinear model (34) to the experimental data.

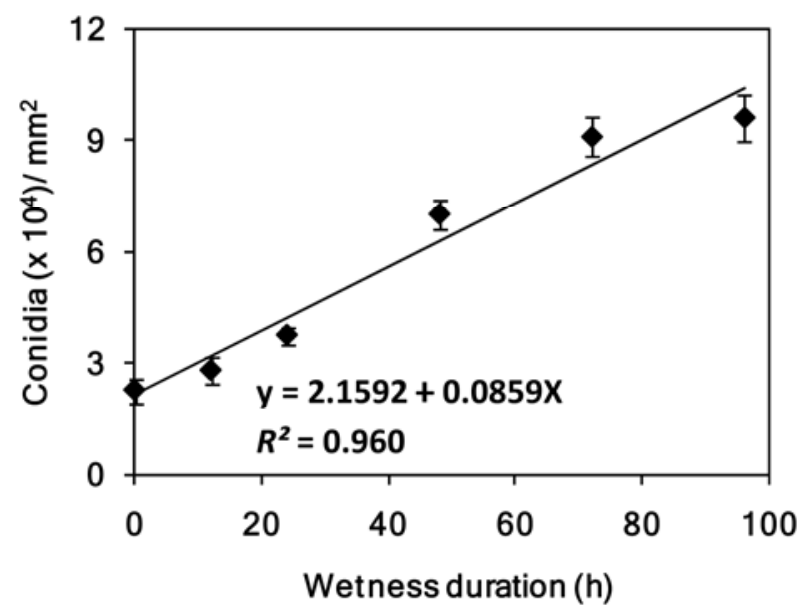

Fig. 3. Effect of wetness duration (h) on the number of Colletotrichum acutatum conidia produced per unit surface area of mummified 'Hojiblanca' olive fruit. Points are the means of 60 replicate mummies, and bars represent the standard error of the mean. The line shows the fit of a simple linear regression model to the experimental data. 
Disease dynamics in the field. In the 3 years of this study, two seasons were favorable for olive anthracnose epidemics (2005-06 and 2006-07) and one season was unfavorable (2007-08). Although spring infection of young fruit was not estimated, the level of quiescent infection of fruit after hot, dry summers was $<1 \%$ in the 3 years. However, latent infection of fruit increased from September to October before the onset of epidemics. In this period, rainfall totals were 409, 327, and $244 \mathrm{~mm}$ in 2005, 2006, and 2007, respectively. At the onset of epidemics in early November, latent infection of fruit varied greatly among years and cultivars (Table 1). On the susceptible Hojiblanca and Picudo, severe epidemics developed during the two favorable seasons. The first symptomatic fruit appeared in early November when the fruit changed color from green-yellow to violet. In addition, some rotted fruit were detected on olive trees adjacent to the experimental orchard at the end of October; however, the fruit in these trees were riper than the fruit in the study. After the first symptomatic fruit were detected, disease incidence and latent infection increased markedly until the end of December. Additionally, there

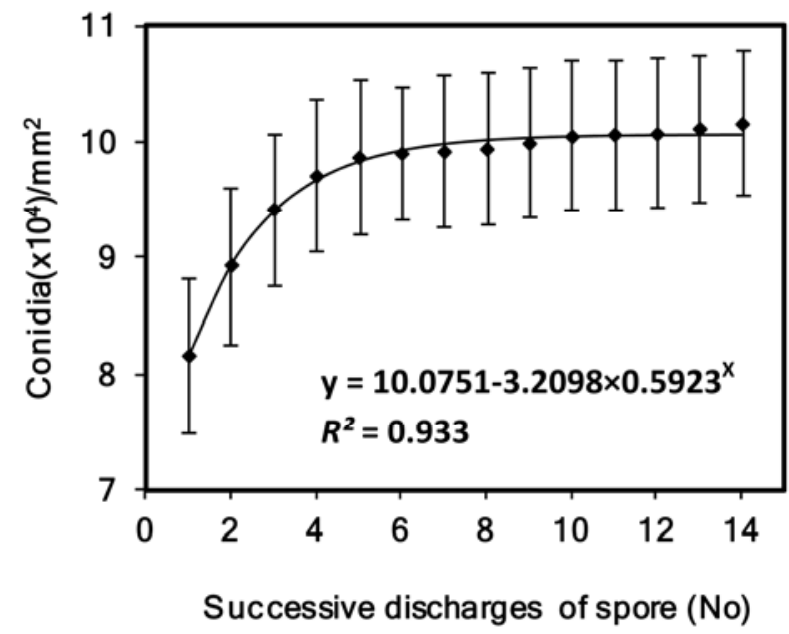

Fig. 4. Effect of repeated incubation followed by washing of mummified 'Hojiblanca' olive fruit infected by Colletotrichum acutatum on the cumulative number of conidia produced per unit surface area of mummy. Fruit were incubated and washed 1 to 14 times; washing simulated removal of conidia by rain. Points are the means of 100 replicate mummies, and bars represent the standard error of the mean. was another important increase of disease incidence during March 2007, when the temperature increased (Fig. 6). On resistant Picual, anthracnose rarely occurred on fruit in the favorable seasons (final incidence of affected fruit <3\%) (Fig. 6; Table 1), and no disease symptoms were observed during the driest season (2007-08) (Table 1). Conversely, the final incidence of affected fruit in the driest season was 12.4 and $0.3 \%$ on Hojiblanca and Picudo, respectively (Table 1). Overall, the dependent variables were not affected $(P>0.05)$ by the orientation of the branches by the cardinal direction during the three seasons (data not shown).

The increase in the incidence of affected fruit over time was adequately described by the Weibull model $\left(R^{2}>0.86\right)$ for the susceptible Picudo and Hojiblanca in the two favorable seasons but no model satisfactorily described the data for susceptible cultivars in the unfavorable season or for resistant Picual in the three seasons because of the low values of disease incidence (Table 1). Although the proportion of symptomatic fruit varied substantially among the six replicated olive trees of each cultivar during both favorable seasons, the effect of cultivar was still significant. The final proportion of affected fruit and AUDPC was generally lower with Picual, although it did not differ significantly $(P>0.05)$ between Picual and Picudo in the season that was unfavorable for disease (Table 1). Of the two susceptible cultivars, Picudo had a significantly $(P<0.05)$ greater final incidence of affected fruit and AUDPC than Hojiblanca in 200506. In 2006-07, however, differences between both cultivars were smaller than in the previous season, although the onset of the epidemic (parameter $\mathrm{C}$ of the Weibull model) was significantly $(P$ $<0.05$ ) delayed by 16.5 days on Hojiblanca relative to Picudo (Table 1). The upper asymptote (A) and accumulated incidence index $(Y)$ of the Weibull model were greater $(P<0.05)$ for Hojiblanca than for Picudo.

The incidence of fruit with latent infection in the olive canopy was frequently greater than the incidence of fruit with visible symptoms, although that difference was especially notable for the resistant Picual (Fig. 6). In the fallen fruit, the percentage of anthracnose-affected fruit was greater than that in the tree canopy for the susceptible Hojiblanca and Picudo in the two favorable seasons (Fig. 6) but there were no differences in the unfavorable season (2007-08) or for the Picual in the three years (data not shown). Among the three cultivars, the fruit ripening rate $(b)$ was lowest for the late-ripening Picudo and highest for the earlyripening Picual, although the rate did not differ between Picual and Hojiblanca in 2006-07 (Table 1). In each susceptible cultivar,

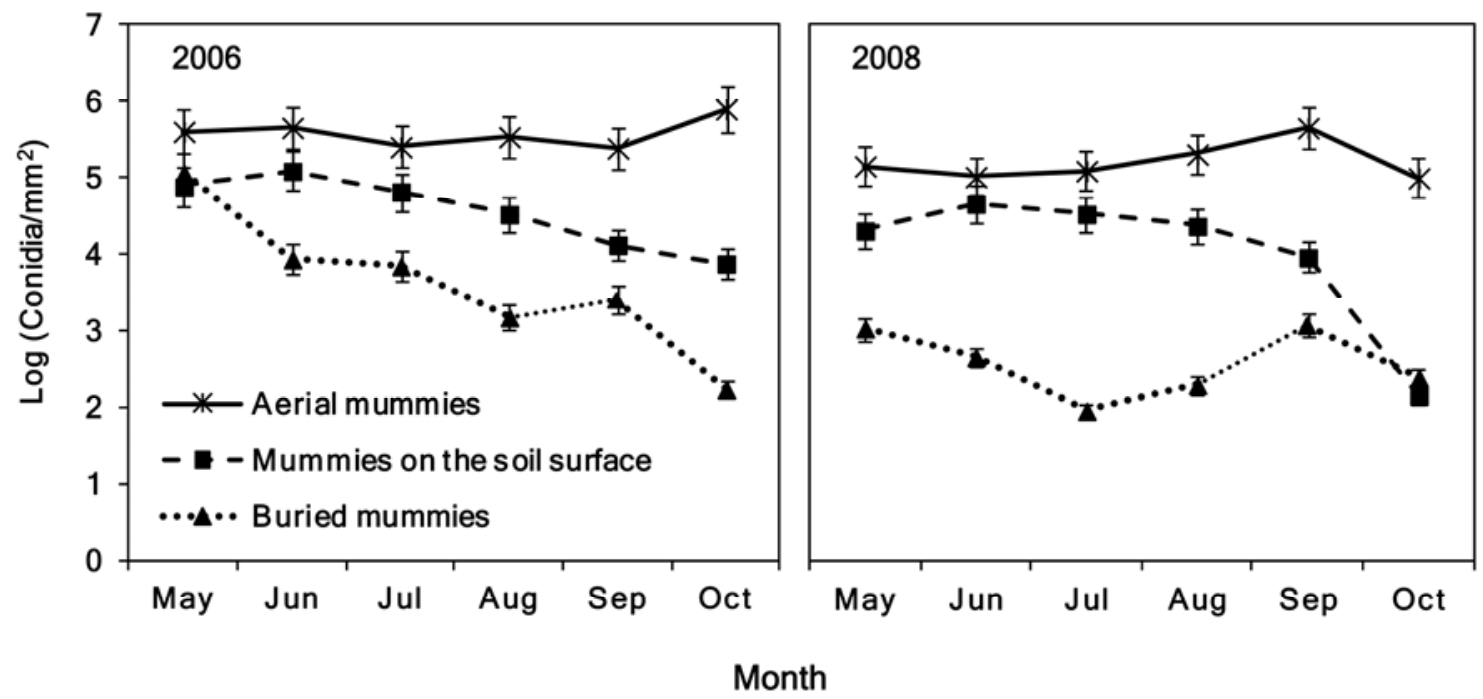

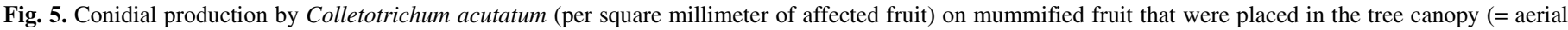

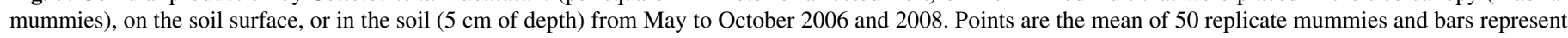
the standard error of the mean. 
the fruit ripening rate of each tree in the three seasons was correlated (Pearson's test; $P<0.05$ ) with the final incidence of affected fruit (Fig. 7). Final incidence of affected fruit of susceptible Hojiblanca and Picudo but not resistant Picual increased linearly with the ripening rate of fruit $\left(R^{2}\right.$ and $R_{a}^{2}>0.600 ; P<$ $0.001)$. The slope of the regression line was greater $(P=0.0008)$ for Picudo than for Hojiblanca (Fig. 7).

\section{DISCUSSION}

Although rotted or mummified fruit have been considered as the main inoculum source for olive anthracnose $(6,17,20,30,31)$, the current study is the first to quantify conidial production on mummified olive fruit. By monitoring symptomatic and nonsymptomatic olive fruit during three seasons in the field, the cur-

TABLE 1. Weibull's model parameters, final incidence (proportion of symptomatic fruit), and area under disease progress curve for anthracnose caused by Colletotrichum acutatum on 'Hojiblanca' (susceptible), 'Picudo' (susceptible), and 'Picual' (resistant) olive in southern Spain ${ }^{\mathrm{t}}$

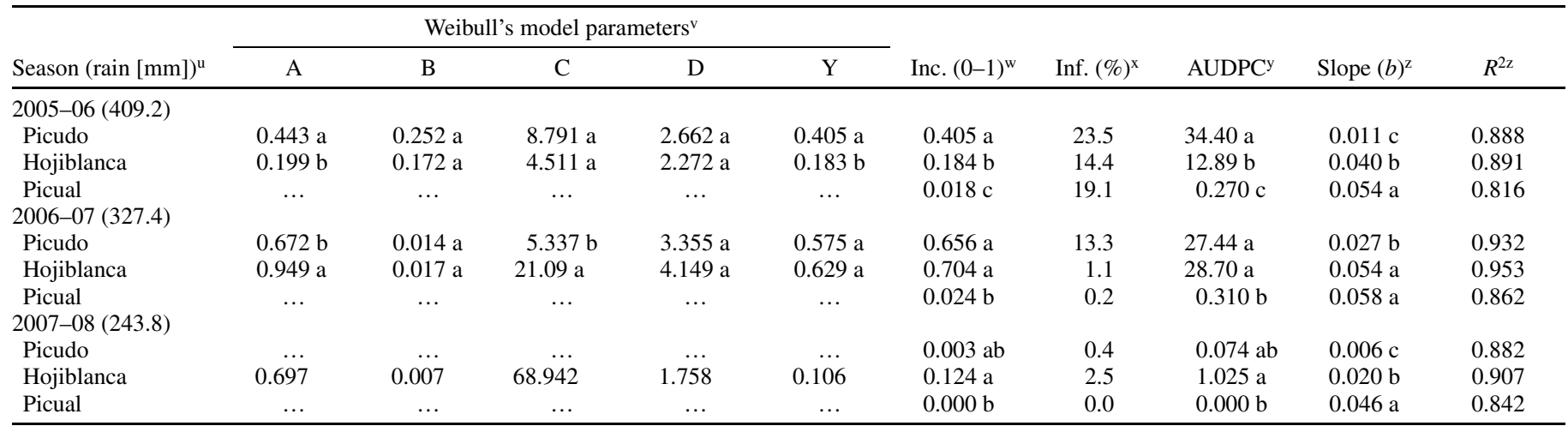

${ }^{t}$ Each value is the mean of data from six olive trees. For each column, means with the same letter are not significantly different according to the least significant differences test at $P=0.05$ or the nonparametric Kruskal-Wallis test at $P=0.05$, depending on normality and homogeneity of variances of data.

u Total autumn rainfall of September, October, and November.

${ }^{v}$ Nonlinear fit of disease progress curve using the Weibull model $\left[Y=A\left(1-\exp \left\{-[B(t-C)]^{D}\right\}\right)\right.$, equation 4$]$ where $A=$ upper asymptote parameter, $B=$ intrinsic rate of $Y$ increase over time, $C=$ length of delay before the onset the epidemic, $D=$ location of inflection point, $Y=$ the final incidence index of the model, and $t=$ time of disease assessment in days.

${ }^{\mathrm{w}}$ Final incidence.

${ }^{x}$ Percentage of fruit with latent infection at the onset of the epidemic in early November.

y Area under disease progress curve (AUDPC) estimated by trapezoidal integration.

${ }^{\mathrm{z}}$ Slope of regressions for fruit ripening from 0 (green) to 4 (black) over time (fruit ripening class [0 to 4$]=\mathrm{a}+b \times t$ [t= time in days]) and its determination coefficient $\left(R^{2}\right)$.
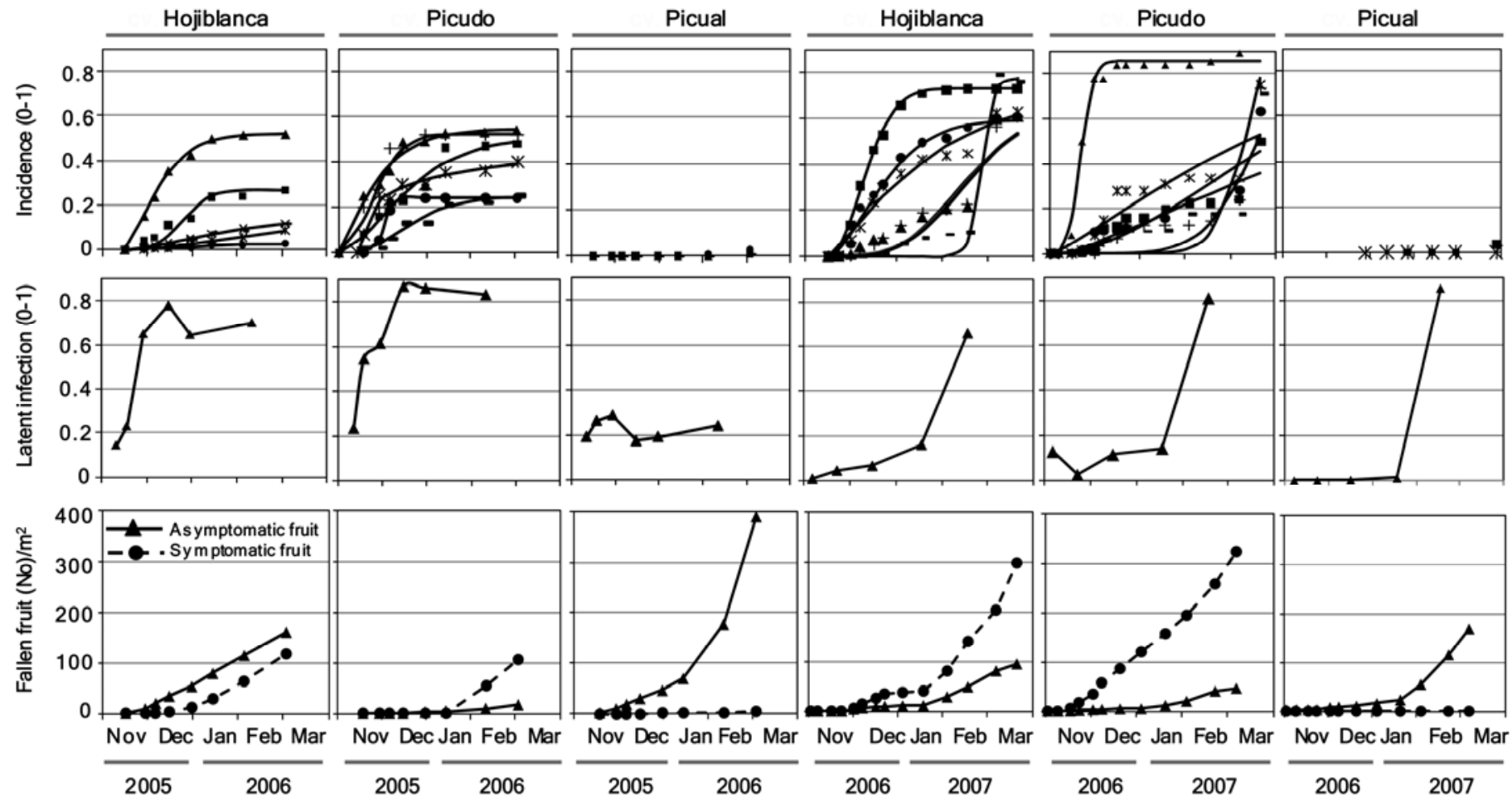

Fig. 6. Progress curves of anthracnose disease caused by Colletotrichum acutatum in 'Hojiblanca' (susceptible), 'Picudo' (susceptible), and 'Picual' (resistant) olive under field conditions in two seasons (2005-06 and 2006-07). In the upper set of graphs (incidence), each symbol represents an individual olive tree and each point is the mean proportion of fruit with anthracnose calculated with data from four cardinal positions, with $\approx 100$ fruit/position. Solid lines represent the predicted disease progress curves calculated by the Weibull function. In the middle set of graphs (latent infection), each point is the mean proportion of latent infection based on 1,000 to 1,500 fruit/cultivar. In the lower set of graphs (fallen fruit), each point represents the mean number of symptomatic or nonsymptomatic fallen fruit per unit area of soil surface as calculated with data from six trees/cultivar. 
rent study also determined disease dynamics and optimal infection periods. In the spring, conidia of the pathogen are dispersed by rain splash from mummified fruit to developing fruit (pea sized), causing quiescent infections. In autumn, when fruit are ripening, the pathogen becomes active, causes fruit rot, and produces large numbers of conidia that initiate secondary disease cycles $(20,30,31)$. At the end of winter, the rotted fruit mummify when humidity decreases and the temperature increases and the mummified fruit, especially those in the tree canopy, are then the main source of conidia for infection of developing fruit during the following spring $(20,31)$.

Others authors, however, have reported that infected leaves and shoots are the major inoculum source for anthracnose infection of developing olive fruit $(5,28)$, because the pathogen can develop secondary conidia (28) or form acervuli in these infected tissues $(14,26,35)$. In a previous study in southern Spain, Moral et al. (20) reported that the pathogen infected the leaves and shoots of olive but did not develop acervuli or conidial masses on these tissues. Artificially infected vegetative tissues only produced conidia when they were incubated at $100 \% \mathrm{RH}$ for more than 1 month (J. Moral and A. Trapero, unpublished data); however, these weather conditions are unlikely to occur in the Mediterranean climate where olives are grown. In field experiments in Spain and Portugal, the percentage of nonsymptomatic infected leaves decreased from the end of winter until summer, when the percentage of pathogen isolation was very low (J. Moral and A. Trapero, unpublished data) (28). Whether or not small numbers of conidia are produced on vegetative tissues, the huge quantity of viable conidia that the fungus produces on mummified fruit $(5 \times$ $10^{8}$ conidia/mummy) suggests that mummies are a much more important inoculum source than leaves and shoots.

Factors influencing conidial production on mummified olive fruit have not been previously reported. In this study, olive cultivar, temperature, and wetness duration influenced conidial production on olive mummies. The optimum temperature range of 20 to $25^{\circ} \mathrm{C}$ observed for conidial production on mummified fruit was similar to that previously reported for germination of conidia $(8,23)$ and infection of fruit $(19)$. However, Kaul and Thakur (9) reported an optimal temperature of 17 to $22^{\circ} \mathrm{C}$ for leaf infection in the field. Likewise, the production of conidia increased with wetness duration in the current study but, when the wetness period was $>96 \mathrm{~h}$, conidial production was reduced, mainly because mummies were colonized by saprophytic microorganisms.

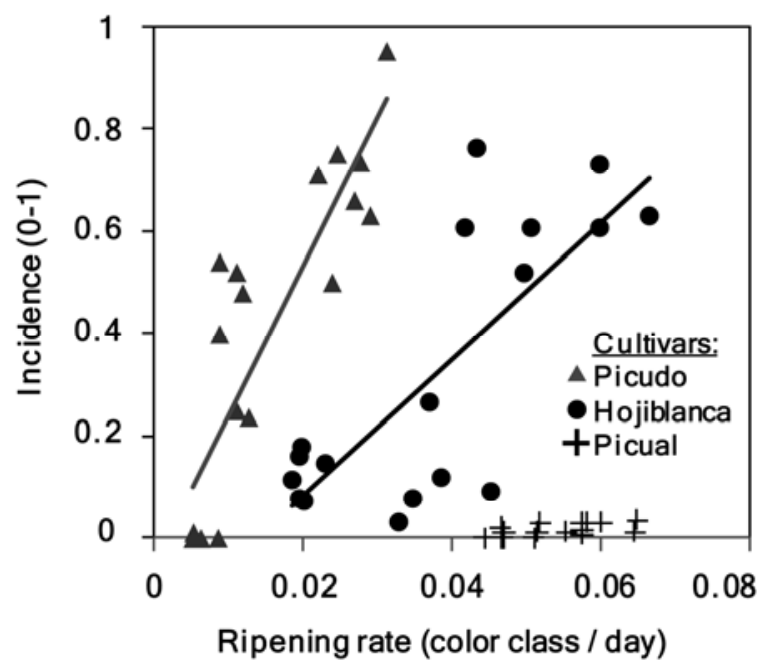

Fig. 7. Relationship between the fruit ripening rate in olive trees of 'Picudo', 'Hojiblanca', and 'Picual' and final incidence of anthracnose caused by $\mathrm{Col}$ letotrichum acutatum. For each cultivar, year, and tree, the ripening rate was calculated as the slope of linear regressions of fruit ripeness (color class from 0 [green fruit] to 4 [black fruit]) (1) over time in days from 1 November to 31 March.
After a moderate or severe epidemic, most mummified fruit fall to the soil surface because the fungus infects the fruit peduncle. Very few mummies $(\approx 1$ mummy/tree) remain in the tree canopy until the next autumn; however, this low number of mummies in the canopy decreased drastically if there was not a new epidemic in the autumn (J. Moral and A. Trapero, unpublished data). MateoSagasta (17) indicated that the fungus might survive as mummies on the soil surface, although other authors suggested that the fungus survives as mummies in the olive canopy (6). In our study, the pathogen produced viable conidia on mummies in the canopy and on and buried in the soil throughout the year but produced $10^{3}$ to $10^{4}$ times more conidia on aerial mummies than on those that were buried in the soil or placed on the soil surface. Mummies in or on the soil were colonized by saprophytic microorganisms and this probably explains the reduction in number of conidia on the mummies in contact with the soil. A similar reduction in conidial numbers on mummies that were buried or on the soil surface has been reported (6,35). Recently, Talhinhas et al. (28) reported that the fungus could not be isolated from mummified fruit collected from the soil surface; however, they checked for the presence of the pathogen in mummies by isolating on PDA rather than by washing the mummies, as was done in our study.

The study of disease dynamics during the autumn-winter period showed that the incidence of fruit with latent or visible infections was highly affected by olive cultivar, weather conditions, and fruit ripeness. There were no epidemics on the resistant cultivar in any season and only minor epidemic development on the susceptible cultivars during the driest season (2007-08). Several authors reported a positive correlation between rainfall during the autumnwinter and disease severity, although this information was based on field observation rather than on systematic study $(9,15,17,28$, 35). Data from our study confirmed that rainfall is an essential factor for olive anthracnose development in susceptible cultivars because it determined the level of latent infection of fruit before the onset of the epidemics (September to October) and the further progress of the epidemics. Moreover, the pathogen presumably can produce large numbers of conidia even after several rainfall periods that were simulated in this study with the washing treatments of mummies.

Like rainfall, temperature influenced the development of anthracnose epidemics on the susceptible cultivars. After the first affected fruit were detected at the beginning of November, incidence of latent-infected and symptomatic fruit increased until the middle of December, when the mean temperature decreased to $\approx 7^{\circ} \mathrm{C}$. Overall, at this time, there were more fruit with latent infections than with symptoms. After that, the proportion of symptomatic fruit increased slowly but most infection remained latent until February to March, when temperature increased again. Other authors have observed that the latent period of the disease is substantially lengthened when the fruit are incubated at low temperatures $(10,19)$.

Fruit susceptibility to anthracnose increases with ripeness $(17,18)$, and fruit ripening was the key factor determining the onset of epidemics on susceptible cultivars in the current study. The onset and rate of fruit ripening, in addition to being affected by temperature and photoperiod, is also influenced by the fruit load on trees (i.e., fruit ripen faster on trees with a lower fruit load) (1). Because the fruit load on trees depends on the previous year's harvest, the yield-reducing factors in a given year, such as anthracnose, increase the onset and rate of ripening in the next year. As a consequence, the occurrence of an anthracnose epidemic in one year increases the probability of an epidemic in the next year. Episodes of concatenated epidemics are well known for olive anthracnose $(15,17,30,31)$.

In this study, the onset of disease and rate of epidemic development varied among trees of each susceptible cultivar. The differences among trees of the same cultivar in the same field are common in olive orchards $(18,21)$ and they appear to be correlated to differences in the rate of fruit ripening of each tree (as 
affected by the fruit load) and to differences in the quantity of available inoculum from the previous year.

The onset and duration of fruit ripening also varies with the cultivar (1), although cultivar susceptibility is not related to the time of fruit ripeness (21). In our study, the ripening rate varied greatly among cultivars and was highest with Picual and lowest with Picudo. In this case, the early fruit ripening of Picual, which should favor anthracnose disease, was balanced by the genetic resistance of this cultivar. Although Hojiblanca and Picudo are highly susceptible to anthracnose, Picudo is slightly more susceptible than Hojiblanca under field conditions because the pathogen can produce symptoms on green fruit of Picudo but it does not do so on green fruit of Hojiblanca (21). This difference in susceptibility influenced the anthracnose epidemic in 2006-07. Thus, the onset of the epidemic (parameter C of Weibull's model) was $\approx 15$ days later in Hojiblanca than in Picudo. Because of the importance of this delay factor, the planting of late-ripening susceptible cultivars has been recommended as a control measure if resistant cultivars are not available $(4,18)$. Also, growers could take advantage of this delay by harvesting early, which is an important practice for controlling the disease $(18,30,31)$.

The effects of wetness duration and temperature on conidial production from mummified fruit and on development of anthracnose in the field and under controlled conditions have been determined in the current study. This information will facilitate the design of a forecasting system that could be used to determine the timing of fungicide sprays and to develop more efficient management strategies. The use of fungicides should be integrated with the exploitation of cultivar resistance, the early harvesting of fruit or the use of cultivars that ripen more slowly, and the elimination of mummified fruit in the olive canopy. These latter methods of anthracnose control should reduce the need for fungicides in olive orchards, which cost olive growers in Spain $>\$ 250$ million/year $(25,32)$.

\section{ACKNOWLEDGMENTS}

This research was funded by the Spanish Ministry of Education and Science (project AGL2004-7495 co-financed by the European Union FEDER Funds) and by the Andalusian Regional Government (project P08-AGR-03635). We thank F. Luque and F. Carmona for their skillful technical assistance with laboratory experiments; B. Jiménez, M. Pérez, and D. Cabello for their assistance in the olive orchards; and W. J. Kaiser, T. J. Michailides, and B. A. Jaffee for critical review of the manuscript.

\section{LITERATURE CITED}

1. Barranco, D., Fernández-Escobar, R., and Rallo, L. 2010. Olive Growing. Junta de Andalucía/Mundi-Prensa/RIRDC/AOA, Pendle Hill, NSW, Australia.

2. Barranco, D., and Rallo, L. 2005. Épocas de floración y maduración. Pages 283-292 in: Variedades de Olivo en España. L. Rallo, D. Barranco, J. M. Caballero, C. Del Rio, C. A. Martín, J. Tous, and I. Trujillo, eds. Junta de Andalucía-Consejería de Agricultura y Pesca, Ministerio de Agricultura, Pesca y Alimentación y Mundi-Prensa, Madrid.

3. Bartolini, G., Petruccelli, R., Tindall, H. D., and Menini, U. G. 2002. Classification, origin, diffusion and history of the olive. FAO, Rome.

4. Bompeix, G., Julio, E. V. R., and Phillips, D. H. 1988. Glomerella cingulata (Stoneman) Spaulding et v. Schrenk. Pages 373-376 in: Manual de Enfermedades de las Plantas. I. M. Smith, J. Dunez, R. A. Lelliot, D. H. Phillips, and S. A. Archer, eds. Mundi-prensa, Madrid.

5. Cacciola, S. O., Pane, A., Agosteo, G. E., and Magnano di San Lio, G. 1996. Osservazioni sull' epidemiologia dell'anthracnosi dell'olivo in Calabria. Inf. Fitopatol. 6:27-32.

6. Graniti, A., Frisullo, S., Pennisi, A.M., and Magnano di San Lio, G. 1993. Infections of Glomerella cingulata on olive in Italy. EPPO Bull. 23:457-465.

7. Hau, B., and Kranz, J. 1990. Mathematics and statistics for analyses in epidemiology. Pages 15-22 in: Epidemics of Plant Diseases. J. Kranz, ed. Springer-Verlag, Berlin.

8. Jurado-Bello, J. 2010. Efecto de la temperatura, tiempo de humectación y potencial osmótico en la infección de aceitunas, germinación de conidios y crecimiento micelial de Colletotrichum spp. agente causal de la Antracnosis del olivo. Trabajo Profesional Fin de Carrera, ETSIAM,
Universidad de Córdoba, Córdoba, Spain

9. Kaul, J. L., and Thakur, R. S. 1985. Incidence of olive anthracnose (Colletotrichum gloeosporioides Penz.) and its correlation with weather conditions. J. Tree Sci. 4:20-34

10. Loprieno, N., and Tenerini, I. 1960. Indagini sul Gloeosporium olivarum Alm., agente della "lebbra" delle olive. Phytopathol. Z. 39:262-290.

11. Madden, L. V., and Campbell, C. L. 1990. Nonlinear disease progress curves. Pages 181-229 in: Epidemics of Plant Diseases, Mathematical Analysis and Modeling, 2nd ed. Ecological Studies 13. J. Kranz, ed. Springer-Verlag, Berlin.

12. Magarey, R. D., Sutton, T. B., and Thayer, C. L. 2005. A simple generic infection model for foliar fungal plant pathogens. Phytopathology 95:92100.

13. Martelli G. P. 1960. Primo contributo alla conoscenza della biologia di Gloeosporium olivarum Alm. Phytopathol. Mediterr. 1:31-43.

14. Martelli, G. P. 1961. Acervuli of Gloeosporium olivarum on olive leaves. Phytopathol. Mediterr. 1:125-128.

15. Martelli, G. P., and Piglionica, V. 1961. Three year trials against olive 'leprosi' in Apulia. Phytopathol. Mediterr. 1:101-112.

16. Martín, M. P., and García-Figueres, F. 1999. Colletotrichum acutatum and C. gloeosporioides cause anthracnose on olives. Eur. J. Plant Pathol. 105:733-741.

17. Mateo-Sagasta, E. 1968. Estudios básicos sobre Gloeosporium olivarum Alm. (Deuteromiceto Melanconial). Bol. Patol. Veg. Entomol. Agric. 30:31-135.

18. Moral, J., Bouhmidi, K., and Trapero, A. 2008. Influence of fruit maturity, cultivar susceptibility, and inoculation method on infection of olive fruit by Colletotrichum acutatum. Plant Dis. 92:1421-1426.

19. Moral, J., Jurado-Bello, J., Sánchez, M. I., Oliveira, R., and Trapero, A. 2012. Effect of temperature, wetness duration, and planting density on olive anthracnose caused by Colletotrichum spp. Phytopathology 102: 974-981.

20. Moral, J., Oliveira, R., and Trapero, A. 2009. Elucidation of the disease cycle of olive anthracnose caused by Colletotrichum acutatum. Phytopathology 99:548-556.

21. Moral, J., and Trapero, A. 2009. Assessing the susceptibility of olive cultivars to anthracnose caused by Colletotrichum acutatum. Plant Dis. 93:1028-1036.

22. Moral, J., Vicente, M., and Trapero, A. 2010. Infected fruit as source of inoculum and infection dynamic on olive anthracnose caused by $\mathrm{Col}$ letotrichum acutatum. (Abstr.) Phytopathology 100:S86.

23. Oliveira, R., Moral, J., Bouhmidi, K., and Trapero, A. 2005. Caracterización morfológica y cultural de aislados de Colletotrichum spp. causantes de la Antracnosis del olivo. Bol. San. Veg. Plagas 31:531-548.

24. Pennypacker, S. P., Knoble, H. D., Antle, C. E., and Madden, L. V. 1980. A flexible model for studying plant disease progression. Phytopathology 70:232-235.

25. Roca, L. F., Moral, J., Viruega, J. R., Ávila, A., Oliveira, R., and Trapero, A. 2007. Copper fungicides in the control of olive diseases. Olea 26:48-50.

26. Sergeeva, V., Spooner-Hart, R., and Nair, N. G. 2008. First report of Colletotrichum acutatum and C. gloeosporioides causing leaf spots of olives (Olea europaea) in Australia. Australas. Plant Dis. Notes 3:143-144

27. Shivas, R. G., and Tan, Y. P. 2009. A taxonomic re-assessment of Colletotrichum acutatum, introducing $C$. fioriniae comb. et stat. nov. and C. simmondsii sp. nov. Fungal Divers. 39:111-122.

28. Talhinhas, P., Mota-Capitão, C., Martins, S., Ramos, A. P., Neves-Martins, J., Guerra-Guimarães, L., Várzea, V., Silva, M. C., Sreenivasaprasad, S., and Oliveira, H. 2011. Epidemiology, histopathology and aetiology of olive anthracnose caused by Colletotrichum acutatum and $C$. gloeosporioides in Portugal. Plant Pathol. 60:483-495.

29. Talhinhas, P., Sreenivasaprasad, S., Neves-Martins, J., and Oliveira, H. 2005. Molecular and phenotypic analyses reveal association of diverse Colletotrichum acutatum groups and a low level of C. gloeosporioides with olive anthracnose. Appl. Environ. Microbiol. 71:2987-2998.

30. Trapero, A., and Blanco, M. A. 2010. Diseases. Pages 521-578 in: Olive Growing. D. Barranco, R. Fernández-Escobar, and L. Rallo, eds. Junta de Andalucía/Mundi-Prensa/RIRDC/AOA, Pendle Hill, NSW, Australia.

31. Trapero, A., and Moral, J. 2008. Anthracnose of olive caused by Colletotrichum spp. Pages 27-28 in: Colletotrichum Diseases of Fruit Crops. N. Peres, and P. Timmer, eds. International Congress of Plant Pathology, Torino, Italy.

32. Trapero, A., Roca, L. F., and Moral, J. 2009. Perspectivas futuras del control químico de las enfermedades del olivo. Phytoma España 212:80-82.

33. Viruega, J. R., Roca, L. F., Moral, J., and Trapero, A. 2011. Factors affecting infection and disease development on olive leaves inoculated with Fusicladium oleagineum. Plant Dis. 95:1139-1146.

34. Yin, X., Kropff, M. J., Mclaren, G., and Visperas, R. M. 1995. A nonlinear model for crop development as a function of temperature. Agric. For. Meteorol. 77:1-16.

35. Zachos, D. G., and Makris, S. A. 1963. Studies on Gloeosporium olivarum in Greece II: Symptoms of the disease. Ann. Inst. Phytopathol. Benaki 5:128-130. 